\title{
Polyaniline Modified with Cobalt-Hexacyanoferrate (PmCH) as an Adsorbent for Removal of Heavy Metals from Aqueous Solutions
}

\author{
Nima Moazezi ${ }^{1, *}$ and Mohammad Ali Moosavian ${ }^{1}$ \\ ${ }^{1}$ School of Chemical Engineering, College of Engineering, University of Tehran, 11155-4563, Tehran, Iran
}

\begin{abstract}
In this study, polyaniline modified with cobalt-hexacyanoferrate $(\mathrm{PmCH})$ composite was synthesized and characterized for removal of $\mathrm{Rb}^{+}, \mathrm{Cd}^{2+}, \mathrm{Zn}^{2+}, \mathrm{Pb}^{2+}$, and $\mathrm{Ni}^{2+}$ by FTIR and XRD. The effect of $\mathrm{pH}$, adsorbent dosage, ionic strength, contact time, initial ion concentration, and temperature were studied. The competition adsorption experiments between metal ions were investigated. Batch desorption was also conducted to evaluate the reusability of $\mathrm{PmCH}$. The maximum adsorption capacities were $96.15,27.17,17.85,19.15$, and $4.76 \mathrm{mg} \mathrm{g}^{-1}$ of $\mathrm{Rb}^{+}, \mathrm{Cd}^{2+}, \mathrm{Zn}^{2+}, \mathrm{Pb}^{2+}$, and $\mathrm{Ni}^{2+}$, respectively. The optimum $\mathrm{pH}$ was determined at natural $\mathrm{pH}$ of each solution.
\end{abstract}

\section{Introduction}

As water pollutants, heavy metals have come up as an interesting area of water research [1]. One of the most popular techniques to removal of these toxic compounds is adsorption process [2]. Due to strong adsorption capability to removal of metal ions, polyaniline can be used as a good prospect for adsorption applications [3]. On the other hands, cobalt-hexacyanoferrate is considered as an effective compound in ion exchange and storage potential of counter cations [4]. In this study, polyaniline modified with cobalt-hexacyanoferrate $(\mathrm{PmCH})$ composite was prepared and characterized for removal of $\mathrm{Rb}^{+}, \mathrm{Cd}^{2+}, \mathrm{Zn}^{2+}, \mathrm{Pb}^{2+}$, and $\mathrm{Ni}^{2+}$ from aqueous solutions.

\section{Materials and Methods}

\subsection{Chemicals and instrumentations}

$\mathrm{Ni}\left(\mathrm{NO}_{3}\right)_{2}$, cobalt (II) chloride hexahydrate, aniline, $\mathrm{HCl}$, $\mathrm{KOH}$, ammonium peroxydisulfate, $\mathrm{Pb}\left(\mathrm{NO}_{3}\right)_{2}, \mathrm{ZnCl}_{2}$, $\mathrm{Cd}\left(\mathrm{NO}_{3}\right)_{2}$, and $\mathrm{RbCl}$ were used in analytical grade (Germany, Merk). FTIR (Bruker, Vector 22) and XRD (STOE, STIDY-MP, Germany) measurements were performed to detect the morphological studies of polyaniline and $\mathrm{PmCH}$. The ion concentrations were analyzed using an ICP-OES (Optima 7300 DV, Perkin Elmer).

\begin{tabular}{|c|c|}
\hline \multicolumn{2}{|c|}{ Nomenclature } \\
\hline $\mathrm{V}$ & Solution volume \\
\hline $\mathrm{C}_{\mathrm{i}} / \mathrm{C}_{\mathrm{e}}$ & Initial / Equilibrium concentration of metal ion \\
\hline $\mathrm{W}$ & Adsorbent weight \\
\hline $\mathrm{q}_{\mathrm{e}} / \mathrm{q}_{\mathrm{t}}$ & Adsorption capacity at equilibrium / at any time \\
\hline $\mathrm{k}_{1} / \mathrm{k}_{2}$ & The rate constant of pseudo-first-order / pseudo-second-order adsorption \\
\hline $\mathrm{h}$ & The initial adsorption rate \\
\hline $\mathrm{k}_{\mathrm{f}} / \mathrm{k}_{\mathrm{L}}$ & The Freundlich constant / Langmuir constant \\
\hline $\mathrm{n}$ & Adsorption intensity and bond energy (Freundlich isotherm) \\
\hline
\end{tabular}

\footnotetext{
*Corresponding author: nmoazezi@ut.ac.ir
} 

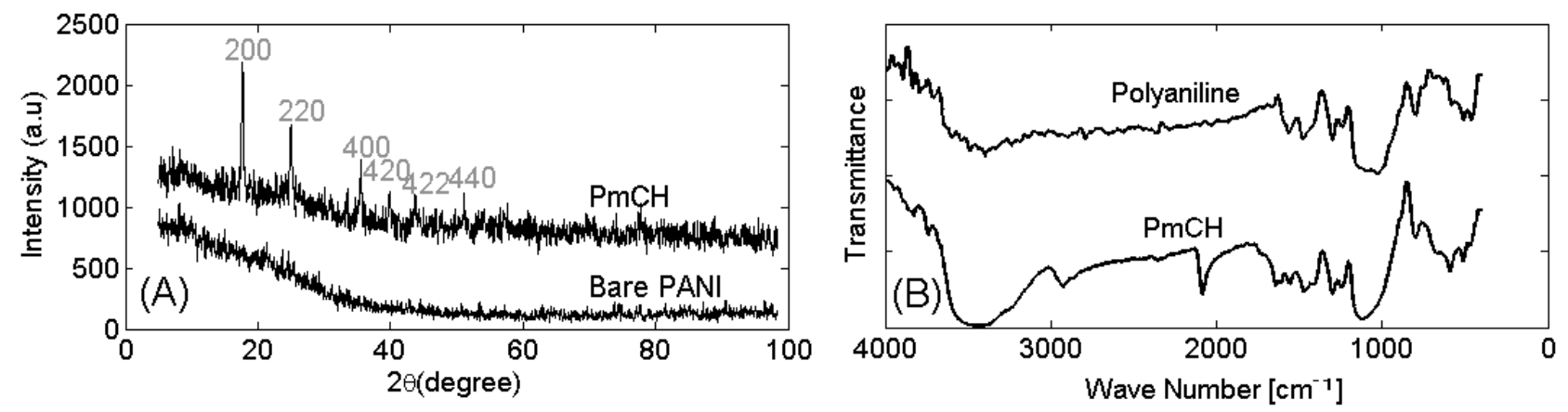

Figure 1. Characterization of polyaniline and PmCH by (A) XRD (B) FTIR.

\subsection{Synthesis of Polyaniline}

Ammonium peroxydisulfate (one gram) was dissolved in $100 \mathrm{~mL}$ of $1 \mathrm{~mol} \mathrm{~L}^{-1} \mathrm{HCl}$ media. After $30 \mathrm{~min}$, one millilitre of aniline was dropwise added to form a dark green solution. After $5 \mathrm{~h}$ of continuous stirring, the solution was filtered and its precipitate was collected. Then, the precipitate was finally washed and dried with distilled water.

\subsection{Synthesis of $\mathrm{PmCH}$}

Cobalt (II) chloride hexahydrate $\left(2 \mathrm{~mol} \mathrm{~L}^{-1}\right)$, potassium ferricyanide $\left(3 \mathrm{~mol} \mathrm{~L}^{-1}\right)$, and ammonium peroxydisulfate (one gram) were dissolved in $100 \mathrm{~mL}$ of $1 \mathrm{~mol} \mathrm{~L}^{-1} \mathrm{HCl}$. After $30 \mathrm{~min}$, one millilitre of aniline was dropwise added to form a dark green solution. After $5 \mathrm{~h}$ of continuous stirring, the solution was filtered and its dry precipitate was collected. Then, the precipitate was finally washed and dried with distilled water at room temperature.

\subsection{Adsorption and desorption of heavy metal ions}

In general, one gram of dry adsorbent was added to 100 $\mathrm{mL}$ of solutions containing $\mathrm{Rb}^{+}, \mathrm{Cd}^{2+}, \mathrm{Zn}^{2+}, \mathrm{Pb}^{2+}$, and $\mathrm{Ni}^{2+}$ ions. These solutions were shaken in a thermostatic shaker. The initial $\mathrm{pH}$ of solution for each ion was adjusted in the range of 2.5 to 9 . In order to evaluate the effects of concentration of heavy metals, the initial concentration of the solutions were considered between 10-100 $\mathrm{mg} \mathrm{L}^{-1}$. The adsorbent dosage was considered at $3.5 \mathrm{gr} \mathrm{L}^{-1}$. The adsorption capacity and ion removal were calculated by [2]:

$$
q_{e}=\frac{C_{i}-C_{e}}{W} \times V \quad ; \quad \text { remova }(\%)=\frac{C_{i}-C_{e}}{C_{i}} \times 100
$$

\section{Equations and mathematics}

\subsection{Characterization of Polyaniline and $\mathrm{PmCH}$}

The XRD patterns of polyaniline and $\mathrm{PmCH}$ are depicted in figure 1A which illustrates that polyaniline and $\mathrm{PmCH}$ have an amorphous and the cubic structures, respectively. The reflections of $\mathrm{PmCH}$ at 200, 220, 400, 420, 422, and 440 were located at $18,24.8,35.5,40.0,43.9$, and $51.0^{\circ}$, respectively (JCPDS 5-0036, 5-0037). The changes in FTIR spectra of polyaniline and $\mathrm{PmCH}$ at $2090 \mathrm{~cm}^{-1}(\mathrm{Fe}-$ $\mathrm{CN}-\mathrm{Co}$ ) indicates that cobalt-hexacyanoferrate have been successfully added to the polyaniline; see figure $1 \mathrm{~B}$. The bands at 788, 1105, 1286, 1444, and $1610 \mathrm{~cm}^{-1}$ correspond to $\mathrm{C}-\mathrm{H}$ bending, $\mathrm{C}-\mathrm{N}$ bonds in the benzenoid rings, $\mathrm{C}-\mathrm{N}$ bonds in the quinoid rings, benzenoid rings, and quinoid rings, respectively [2]. A broad bond at around $3100-3650$ and $2850-2950 \mathrm{~cm}^{-1}$ are assigned to $\mathrm{O}-\mathrm{H}$ stretching for the hydrogen bonded hydroxyl groups and the alkyl stretching groups, respectively [3].

\subsection{Effect of pH}

The effects of initial $\mathrm{pH}$ on the adsorption of each metal ion onto $\mathrm{PmCH}$ were evaluated at $\mathrm{pH}$ 2-6 and an initial ion concentration of $100 \mathrm{mg} \mathrm{L}^{-1}$. As can be seen in figure $2 \mathrm{~A}$, adsorption capacity of $\mathrm{PmCH}$ was enhanced with increasing the $\mathrm{pH}$. At low $\mathrm{pH}$, the surface of $\mathrm{PmCH}$ has a positive charge. The negative charge density of $\mathrm{PmCH}$ surface was increasing with increasing the $\mathrm{pH}$. At $\mathrm{pH}$ above the zero point charge, the functional groups of $\mathrm{PmCH}$ surface have the negative charge; hence, maximum cation sorption occurs at high $\mathrm{pH}$ [5]. At high $\mathrm{pH}$, due to salt formation of $\mathrm{Cd}^{2+}, \mathrm{Zn}^{2+}, \mathrm{Pb}^{2+}$, and $\mathrm{Ni}^{2+}$ some precipitations were appeared. So, these studies do not continued more than precipitations $\mathrm{pH}$. Fortunately, the optimum $\mathrm{pH}$ was determined at natural $\mathrm{pH}$ of each solution. 

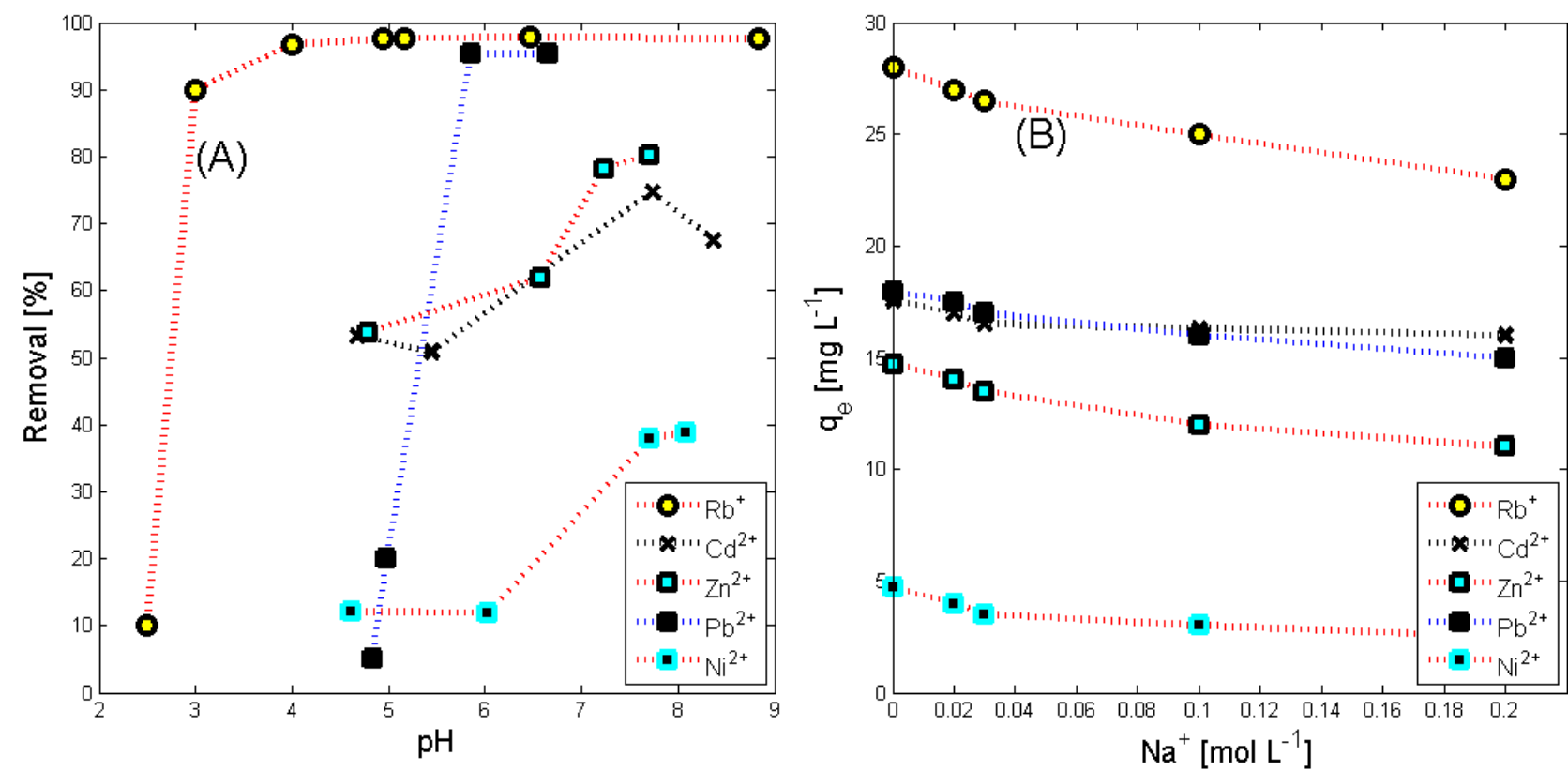

Figure 2. Effect of (A) $\mathrm{pH}(\mathrm{B})$ ionic strength (initial concentration: $100 \mathrm{mg} \mathrm{L}^{-1}$ ).

\subsection{Effects of ionic strength}

The effect of ionic strength was evaluated by adding five different concentrations of $\mathrm{NaNO}_{3}$ at $100 \mathrm{mg} \mathrm{L}^{-1}$ of initial metal concentration; see figure 2B. $\mathrm{NaNO}_{3}$ as an inorganic salt plays an important roles in aqueous solution. The adsorption of metal ion on $\mathrm{PmCH}$ was decreased with a raise of $\mathrm{NaNO}_{3}$ concentration due to performance of salt screens as an electrostatic interaction factor of the opposite charges between metal ions and $\mathrm{PmCH}$ surface [1].

\subsection{Effects of contact time and adsorption kinetics}

The effect of contact time between each ion and $\mathrm{PmCH}$ was studied at $3.5 \mathrm{~g} \mathrm{~L}^{-1} \mathrm{PmCH}$ dosage and $100 \mathrm{mg} \mathrm{L}^{-1}$ ion concentration, which illustrated that the adsorption of ion was as a function of contact time. The pseudo-first-order (equation 2) and the pseudo-second-order kinetic (equation 3) models have been applied to determine and describe the kinetic process of liquid-solid phase [2]:

$\ln \left(q_{e}-q_{t}\right)=\ln q_{e}-k_{1} t$

$$
\left(t / q_{t}\right)=\left(1 / k_{2} q_{e}^{2}\right)+\left(t / q_{e}\right) \quad ; \quad h=k_{2} q_{e}^{2}
$$

Studies showed that more than $90 \%$ of the total adsorption occurs within the first 100-150 min and the concentration approached their equilibrium value at 200$400 \mathrm{~min}$, which can be confirmed by h value in Table 1 . The initial adsorbent rate of $\mathrm{Rb}^{+}$was clearly more than the others. By comparing the correlation coefficient $R^{2}$, it appears that the pseudo-second-order kinetic fits the experimental data more accurately than the pseudosecond-order kinetic. This model suggests that ions are exchanged with hydrogen on the $\mathrm{PmCH}$ surface [3].

\subsection{Equilibrium studies in single-component system}

The effect of initial concentrations of each ion was carried out using Langmuir (equation 4) and Freundlich (equation 5) models within range of $10-100 \mathrm{mg} \mathrm{L}^{-1}$ of ions at $25^{\circ} \mathrm{C}[5]$ :

$$
\begin{aligned}
& \left(C_{e} / q_{e}\right)=\left(1 / q_{\max } k_{L}\right)+\left(C_{e} / q_{\max }\right) \\
& \log q_{e}=\log k_{f}+(1 / n) \log C_{e}
\end{aligned}
$$

The adsorption capacities were increased with increasing

Table 1. The kinetics parameters for adsorption of ions using $\mathrm{PmCH}$.

\begin{tabular}{|l|l|l|l|l|l|l|}
\hline \multirow{2}{*}{ Ion } & \multirow{2}{*}{$\mathrm{q}_{\mathrm{e}}\left[\mathrm{mg} \mathrm{g}^{-1}\right]$} & \multicolumn{2}{l|}{ Pseudo-second-order } & \multicolumn{2}{l|}{ Pseudo-first-order } \\
\cline { 3 - 7 } & & $\mathrm{k}_{2}\left[\mathrm{~g} \mathrm{mg}^{-1} \mathrm{~min}^{-1}\right]$ & $\mathrm{h}\left[\mathrm{mg} \mathrm{g}^{-1} \mathrm{~min}^{-1}\right]$ & $\mathrm{R}^{2}$ & $\mathrm{k}_{1}\left[\mathrm{~min}^{-1}\right]$ & $\mathrm{R}^{2}$ \\
\hline $\mathrm{Rb}^{+}$ & 96.15 & 0.0008 & 0.6803 & 0.997 & 0.0076 & 0.903 \\
\hline $\mathrm{Cd}^{2+}$ & 27.17 & 0.0005 & 0.1786 & 0.979 & 0.0070 & 0.980 \\
\hline $\mathrm{Zn}^{2+}$ & 17.85 & 0.0007 & 0.1786 & 0.989 & 0.0047 & 0.971 \\
\hline $\mathrm{Pb}^{2+}$ & 19.15 & 0.0009 & 0.3199 & 0.995 & 0.0041 & 0.949 \\
\hline $\mathrm{Ni}^{2+}$ & 4.76 & 0.0015 & 0.0381 & 0.984 & 0.0068 & 0.990 \\
\hline
\end{tabular}


the initial concentration of each ion. $\mathrm{q}_{\max }, \mathrm{k}_{\mathrm{L}}, \mathrm{k}_{\mathrm{f}}$, and $\mathrm{n}$ parameters were calculated from the slope and intercept of the above equations plots. The correlation coefficient $\left(\mathrm{R}^{2}\right)$ of Langmuir model (for all of ions were in the range of 0.992-0.998) fits the experimental data better than that of Freundlich isotherm (for all of ions were in the range of 0.819-0.965) which indicates that $\mathrm{PmCH}$ has a homogeneous surface, with equal energy in its activate sites. The maximum adsorption capacities were 96.15, $27.17,17.85,19.15$, and $4.76 \mathrm{mg} \mathrm{g}^{-1}$ of $\mathrm{Rb}^{+}, \mathrm{Cd}^{2+}, \mathrm{Zn}^{2+}$, $\mathrm{Pb}^{2+}$, and $\mathrm{Ni}^{2+}$, respectively. The $\mathrm{k}_{\mathrm{L}}$ parameters were 0.176, 0.064, 0.110, 0.515, and $0.212 \mathrm{~L} \mathrm{mg}^{-1}$ of $\mathrm{Rb}^{+}, \mathrm{Cd}^{2+}$, $\mathrm{Zn}^{2+}, \mathrm{Pb}^{2+}$, and $\mathrm{Ni}^{2+}$, respectively.

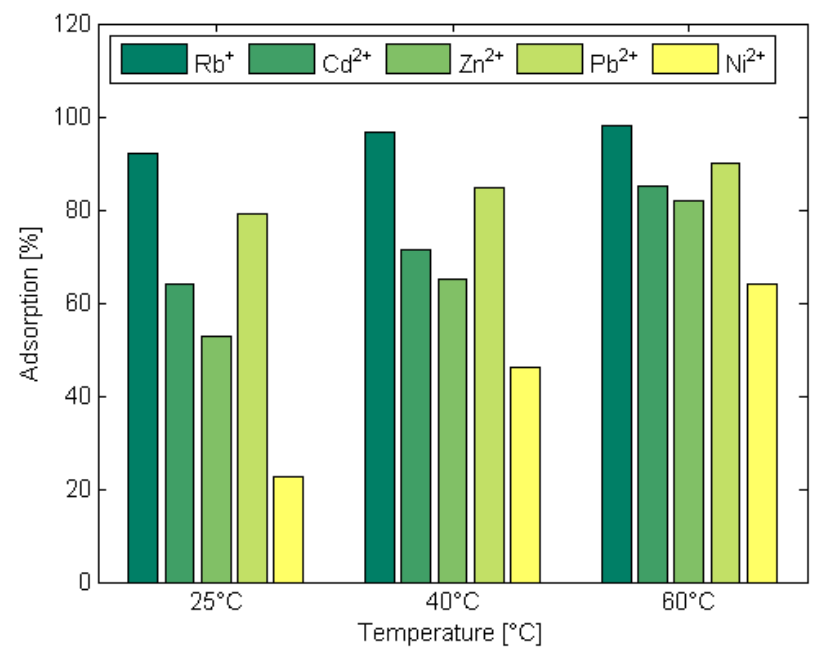

Figure 3. Effect of temperature at 25,40 , and $60^{\circ} \mathrm{C}$ (initial concentration: $100 \mathrm{mg} \mathrm{L}^{-1}$ ).

\subsection{Effects of temperature}

The effects of temperature on the adsorption of heavy
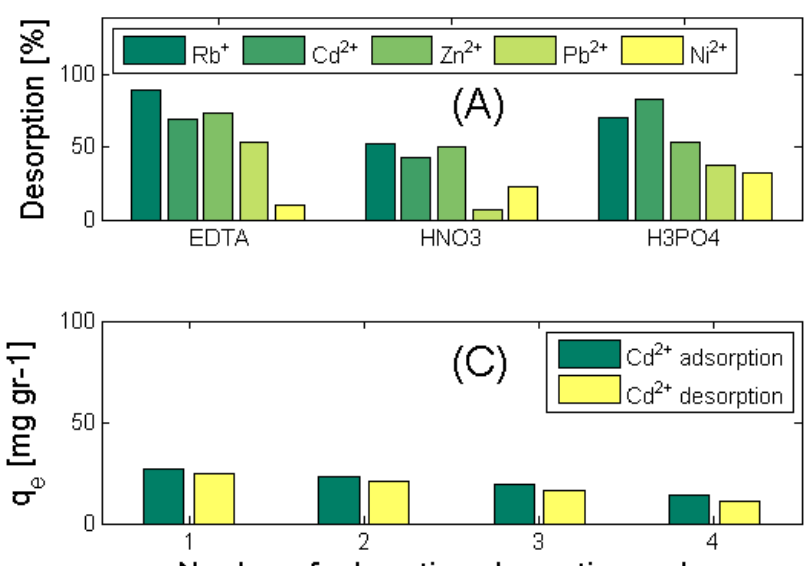

Number of adsorption-desorption cycles

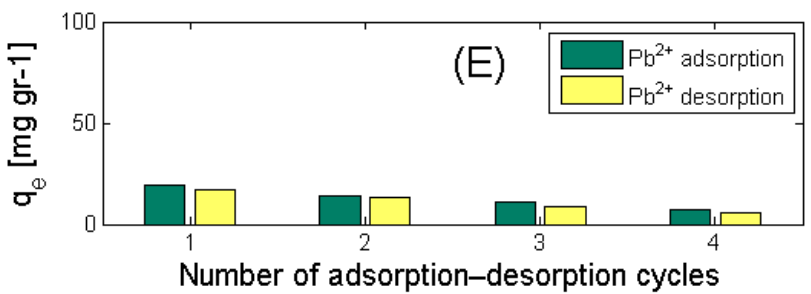

metals onto $\mathrm{PmCH}$ were evaluated at three different temperatures $\left(25,40\right.$, and $\left.60{ }^{\circ} \mathrm{C}\right)$ and $100 \mathrm{mg} \mathrm{L}^{-1}$ of initial metal concentration; see figure 3 . The adsorption capacity of each heavy metal onto $\mathrm{PmCH}$ was increased with increasing the temperature, which indicates that the adsorption of heavy metals onto $\mathrm{PmCH}$ is endothermic process.

Enhance of adsorption capacity with increasing the temperature is due to the strengthening of adsorptive forces between the adjacent molecules of the adsorbed phase, and between the ion species and active sites of the $\mathrm{PmCH}$.

\subsection{Multi-component adsorption (in binary mixtures)}

To determine the competitive effect of ions on each other in binary mixture, removal percentage of 1st ion are shown in Table 2 at $3.5 \mathrm{~g} \mathrm{~L}^{-1} \mathrm{PmcH}$ dosage and $100 \mathrm{mg}$ $\mathrm{L}^{-1}$ ion concentration. The removal percentage of $\mathrm{Rb}^{+}$(as the 1 st ion) in the presence of $\mathrm{Cd}^{2+}, \mathrm{Zn}^{2+}, \mathrm{Pb}^{2+}$, and $\mathrm{Ni}^{2+}$ (as the 2nd ion) were $84.3,89.7,84.1$, and 91.5 percent. However, the removal percentage of $\mathrm{Cd}^{2+}, \mathrm{Zn}^{2+}, \mathrm{Pb}^{2+}$, and $\mathrm{Ni}^{2+}$ (as the 1st ion) in the presence of $\mathrm{Rb}^{+}$(as the 2nd ion) were 32.1, 22.1, 46.7, and 9.3 percent. These results illustrate that $\mathrm{Rb}^{+}$was more to be adsorbed onto $\mathrm{PmCH}$ even in binary mixture. The rank of removal efficiency in binary mixtures was $\mathrm{Rb}^{+}>\mathrm{Pb}^{2+}>\mathrm{Cd}^{2+}>\mathrm{Zn}^{2+}>\mathrm{Ni}^{2+}$ which can be explained by Lewis acids low and classification of heavy metals in metal into class-B 'soft ions', class-A 'hard ions' and borderline ions [1]. $\mathrm{Rb}^{+}$, $\mathrm{Cd}^{2+}, \mathrm{Pb}^{2+}, \mathrm{Zn}^{2+}$ and $\mathrm{Ni}^{2+}$ on the basis of the Lewis acids low are classified in $\mathrm{A}, \mathrm{B}, \mathrm{B}$, borderline, and borderline, respectively [6].
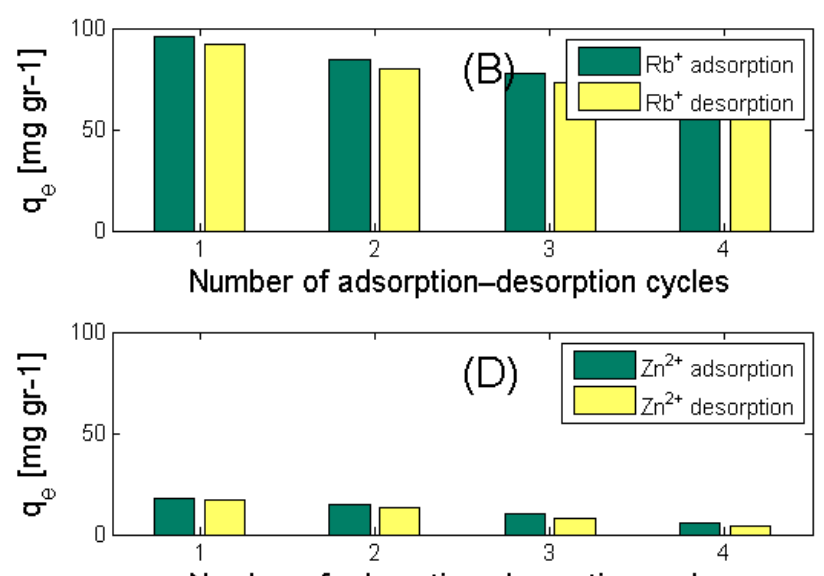

Number of adsorption-desorption cycles

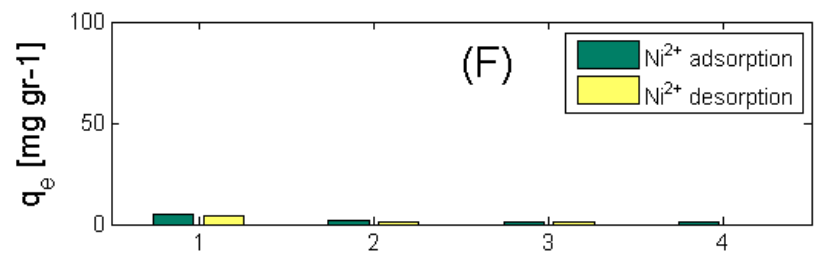

Number of adsorption-desorption cycles

Figure 4. Effect (A) Desorption percentage of ions from $\mathrm{PmCH}$ using three different buffers. Adsorption-desorption cycles of $\mathrm{PmCH}$ for (B) $\mathrm{Rb}^{+}-$EDTA, (C) $\mathrm{Cd}^{2+}-\mathrm{H}_{3} \mathrm{PO}_{4}$, (D) $\mathrm{Zn}^{2+}$-EDTA, (E) $\mathrm{Pb}^{2+}$-EDTA, and (F) $\mathrm{Ni}^{2+}-\mathrm{H}_{3} \mathrm{PO}_{4}$. 
Table 2. PmCH Removal percentage based on 1 st ion removal in binary mixtures at $25^{\circ} \mathrm{C}$.

\begin{tabular}{|l|l|l|l|l|l|}
\hline 1 st ion & \multicolumn{4}{l}{ 2nd ion } \\
\hline & $\mathrm{Rb}^{+}$ & $\mathrm{Cd}^{2+}$ & $\mathrm{Zn}^{2+}$ & $\mathrm{Pb}^{2+}$ & $\mathrm{Ni}^{2+}$ \\
\hline $\mathrm{Rb}^{+}$ & - & 84.3 & 89.7 & 84.1 & 91.5 \\
\hline $\mathrm{Cd}^{2+}$ & 32.1 & - & 54.4 & 48.0 & 59.3 \\
\hline $\mathrm{Zn}^{2+}$ & 22.1 & 39.4 & - & 36.5 & 48.2 \\
\hline $\mathrm{Pb}^{2+}$ & 46.7 & 53.5 & 68.2 & - & 75.3 \\
\hline $\mathrm{Ni}^{2+}$ & 9.3 & 9.9 & 16.4 & 6.8 & - \\
\hline
\end{tabular}

\subsection{Desorption and reusability}

Desorption studies of metal ions were carried out to evaluate the reusability of $\mathrm{PmCH}$ using three different buffers (EDTA, $\mathrm{HNO}_{3}$, and $\mathrm{H}_{3} \mathrm{PO}_{4}$ ); see figure 4. The best buffers for excellent desorption efficiency for $\mathrm{Rb}^{+}$, $\mathrm{Cd}^{2+}, \mathrm{Zn}^{2+}, \mathrm{Pb}^{2+}$, and $\mathrm{Ni}^{2+}$ ions were EDTA, $\mathrm{H}_{3} \mathrm{PO}_{4}$, EDTA, EDTA, $\mathrm{H}_{3} \mathrm{PO}_{4}$, respectively (figure 4A). The coordination ligands of each buffer formed a strong bonding with a selective ion, when each buffer was added to the ion adsorbed-PmCH. Ion-ligand bonding Strength was the determining factor for making more easily desorb from the $\mathrm{PmCH}$. The reusability of $\mathrm{PmCH}$ using the selective buffer for each ion by following four cycles of adsorption-desorption process was shown in figure 4B-F. The negligible changes of adsorption-desorption cycles indicate that $\mathrm{PmCH}$ is an adsorbent with no irreversible sites and can be used as a reusable adsorbent in wastewater treatment.

\section{Conclusions}

PmCH was synthesized and characterized for removal of heavy metals by FTIR and XRD. The adsorption of metal ion was decreased with a raise of $\mathrm{NaNO}_{3}$ concentration. The Langmuir isotherm and pseudo-second-order kinetic models fit the experimental data better than the others. The maximum adsorption capacities were 96.15, 27.17, 17.85, 19.15, and $4.76 \mathrm{mg} \mathrm{g}^{-1}$ of $\mathrm{Rb}^{+}, \mathrm{Cd}^{2+}, \mathrm{Zn}^{2+}, \mathrm{Pb}^{2+}$, and $\mathrm{Ni}^{2+}$, respectively. The adsorption capacity of each ion was increased with increasing the temperature. The rank of removal efficiency in binary mixtures was $\mathrm{Rb}^{+}>$ $\mathrm{Pb}^{2+}>\mathrm{Cd}^{2+}>\mathrm{Zn}^{2+}>\mathrm{Ni}^{2+}$. The best buffers for excellent desorption efficiency for $\mathrm{Rb}^{+}, \mathrm{Cd}^{2+}, \mathrm{Zn}^{2+}, \mathrm{Pb}^{2+}$, and $\mathrm{Ni}^{2+}$ ions were EDTA, $\mathrm{H}_{3} \mathrm{PO}_{4}$, EDTA, EDTA, $\mathrm{H}_{3} \mathrm{PO}_{4}$, respectively.

\section{References}

1. A.Z. Badruddoza, Z.B. Shawon, W.J. Tay, K. Hidajat, M.S. Uddin, Carbohydr. Polym. 91, 1 (2013)

2. M.A. Moosavian, N. Moazezi, Desalin. Water. Treat. 57, 44 (2016)

3. N. Moazezi, M.A. Moosavian, J. Environ. Chem. Eng. 4, 2 (2016)

4. H. Li, Q. Gao, L. Chen, W. Hao, Sensors Actuators, B Chem. 173, (2012)

5. T. Yousefi, M. Torab-Mostaedi, M.A. Moosavian, H. Ghasemi Mobtaker, Prog. Nucl. Energy 85, (2015)

6. L. Yang, S. Wu, J.P. Chen, Ind. Eng. Chem. Res. 46, (2007) 